\title{
Habitat use by white-tailed deer on cross timbers rangeland following brush management
}

\author{
DAVID M. LESLIE, JR, RODERICK B. SOPER, ROBERT L. LOCHMILLER, AND DAVID M. ENGLE
}

\begin{abstract}
Authors are unit leader, U.S. National Biological Service, Oklahoma Cooperative Fish and Wildlife Research Unit; former research assistant and professor, Department of Zoology; and professor, Department of Agronomy, Oklahoma State University, Stillwater, Okla. 74078. Present address for Roderick B. Soper: Phenix Environmental, Inc., 30 Broadway, Suite 207, Kingston, N.Y. 12401. Reprint requests should be sent to David Leslie
\end{abstract}

Abstract

Seasonal habitat use by white-tailed deer (Odocoileus virginianus Zimmerman) was monitored with radio telemetry in 1988-89 to determine responses to experimental brush treatments, 5-6 years post-treatment, in the cross timbers region of central Oklahoma. The study area was a mosaic of brush treatments: tebuthiuron (N-[5-(1,1-dimethylethyl)-1,3,4-thiazol-2-y1]-N,N'-dimethylurea) herbicide, tebuthiuron with an annual spring burn, triclopyr ([(3,5,6-trichlor-2-pyridinyl)oxy] acetic acid) herbicide, triclopyr with an annual spring burn, and no herbicide with annual spring burning. Control areas with no burning or herbicide applications also were evaluated. Herbicides were applied in 1983, and fires were initiated in 1985. Annual home range (95\% harmonic mean) averaged 99.9 ha, and no differences in size among seasons or between sexes were observed. Both sexes selected and avoided specific brush treatments throughout the year. Female deer selected or avoided more human-altered habitats in specific contrasts of main treatment groups (e.g., treated vs. control, herbicide vs. no herbicide, fire vs. no fire, etc.) than males. Both sexes selected fire treatments in summer and were most particular in their choice of main treatment groups in summer and fall. Habitat use between the sexes was most similar in winter and most disparate in fall. The mosaic of habitat types resulting from the variable herbicide and burn application pattern probably influenced deer habitat use in the cross timbers region through combined effects of increased mid-story cover and forage production as they relate to reproductive activities and nutritional needs of female deer in particular.

Key Words: white-tailed deer, Odocoileus virginianus, herbicides, prescribed burning, habitat use, Oklahoma.

The cross timbers is a western extension of the Ozark plateau, oak-hickory ecosystem and contains about 19 million ha of

\footnotetext{
This study was funded by the Departments of Agronomy and Zoology, Oklahoma State University; Oklahoma Cooperative Fish and Wildlife Research Unit (U.S. Natl. Biol. Serv., Okla. Dep. Wildl. Conserv., Okla. State Univ., and Wildl. Manage. Inst, cooperating); National Science Foundation (BSR-8567043), and Oklahoma Agricultural Experiment Station. We are grateful to K. J. Jenkins and J. A. Jenks for reviews of earlier drafts of this manuscript. This is a journal article of the Oklahoma Agricultural Experiment Station.

Manuscript accepted 20 Nov. 1995.
}

upland hardwood forest-tallgrass prairie in the central United States (Garrison et al. 1977, Soil Conser. Serv. 1981). Livestock production in these oak-dominated rangelands is relatively low due to poor production of herbaceous forage (Scifres 1980). Brush management programs that selectively remove unwanted woody species and increase herbaceous forage production (e.g., herbicides and fire) can benefit both white-tailed deer and livestock (Darr and Klebenow 1975, Scifres 1980, Rollins 1987).

Habitat use by white-tailed deer after removal of woody overstory with herbicides and fire has not been examined in cross timbers rangeland. Our recent work there, however, suggested that (1) herbicide treatment can improve browse quality up to 6 years post-treatment (Soper et al. 1993a) and (2) concomitant increases in diet quality may influence physical condition of deer because they are heavier on treated areas than nontreated areas (Soper et al. 1993b). In other habitat types, initial improvements in browse and forb production have been demonstrated following applications of 2,4,5-T ((2,4,5-trichlorophenoxy) acetic acid), picloram (4-amino-3,5,6-trichloropicolinic acid), 2,4-D ((2,4-dichlorophenoxy) acetic acid), tebuthiuron (N-[5-(1,1-dimethylethyl)-1,3,4thiazol-2-y-1]-N,N'-dimethylurea), triclopyr ([(3,5,6-trichlor-2pyridinyl)oxy] acetic acid), and glyphosate ( $\mathrm{N}$-(phosphonomethyl)glycine) (Scifres and Mutz 1978, Scifres 1980). Behavioral and populational responses of white-tailed deer to herbicide-induced vegetation changes vary considerably and appear to be partly dependent on habitat type and region (Davis and Winkler 1968, Beasom and Scifres 1977, Quinton et al. 1979, Beasom et al. 1982, Inglis 1983, Rollins et al. 1988, Fulbright and Garza 1991).

Our objective was to evaluate habitat use by female and male white-tailed deer on areas treated with herbicides, prescribed fire, and both in the cross timbers. White-tailed deer generally respond favorably to such human-induced habitat alterations, which create edge and early succesional communities (Crawford 1984, Smith 1991). Chemical and mechanical brush management techniques are used primarily to set back successional stages to increase primary production (Scifres 1980). As a result, we hypothesized that white-tailded deer would selectively use herbicide-treated and burned cross timbers rangeland. We also hypothesized that female and male deer would use disparate treated habitats seasonally depending on their physiological and behavioral needs relative to reproduction (Jenks et al. 1994). 


\section{Study Area}

The Cross Timbers Experimental Range (CTER), located 11 $\mathrm{km}$ southwest of Stillwater, Oklahoma $\left(36^{\circ} 3^{\prime} \mathrm{N}, 97^{\circ} 10^{\prime} \mathrm{W}\right)$, is a 640-ha research area that was established in 1983 to evaluate responses of vegetation, livestock, and wildlife to management of woody vegetation. The CTER was divided into 20 fenced 32-ha pastures of 5 brush treatments in a completely randomized design with 4 blocks: (1) tebuthiuron; (2) tebuthiuron with annual spring burn; (3) triclopyr; (4) triclopyr with annual spring burn; and (5) untreated controls. Two additional pastures with annual spring burns but no herbicide treatment and control areas with no burning or herbicide applications adjacent to the Experimental Range also were included in this study. Each herbicide was applied aerially at a rate of $2.2 \mathrm{~kg}$ a.i. ha ${ }^{-1}$ (tebuthiuron, Mar 1983; triclopyr, June 1983), and prescribed burning was done in April 1985 to 1987. Therefore, habitat use by white-tailed deer of treatments was evaluated 5-6 years post-herbicide treatment.

Upland hardwood forests were dominated by blackjack oak ( $Q$ uercus marilandica Muenchh.) and post oak ( $Q$. stellata Wangenh.) on coarse-textured soils; tallgrass prairie was interspersed throughout the (CTER) on fine-textured soils (Ewing et al. 1984, Gray and Stanke 1970); and bottomland forests were restricted to intermittent stream bottoms. Treatments were blocked by the soil and cover types of individual pastures to ensure thorough representation of upland/bottomland forests and prairie in the experimental design. Understory woody species were dominated by coralberry (Symphoricarpos orbiculatus Moench.), eastern redcedar (Juniperus virginiana L.), poison ivy (Rhus radicans $\mathrm{L}$.), roughleaf dogwood (Cornus drummondi Meyer), redbud (Cercis canadensis L.), and American elm (Ulmus americana L.). Dominant herbaceous vegetation included little bluestem [Schizachrium scoparium (Michx.) Nash], indiangrass [Sorghastrum nutans (L.) Nash], western ragweed (Ambrosia psilostachya D.C.), and rosette panicgrass (Panicnum oligasanthes Schultes) (Ewing et al. 1984).

Before treatment, upland forests varied from open hardwood overstories with productive herbaceous forage to closed overstories with negligible understory production (Lochmiller et al. 1995). Tebuthiuron greatly reduced hardwood understory and overstory and increased herbaceous production (Engle et al. 1991, Stritzke et al. 1991). Triclopyr reduced hardwood oversto$\mathrm{ry}$, moderately increased herbaceous production, and produced a dense understory of resprouting and herbicide-resistant woody species. Tebuthiuron had a more consistent tree kill (52 to 99\%) than triclopyr (8 to 100\%) (Stritzke et al. 1987). Untreated habitats had a dense woody canopy, little herbaceous cover, and moderate amounts of woody understory (Engle et al. 1991, Stritzke et al. 1991). Prescribed burning did not greatly alter woody vegetation, but it reduced cover of eastern redcedar (Stritzke et al. 1991), improved gains of stocker cattle (McCollum et al. 1987), and increased nutritional quality of selected herbaceous forages (Bogle et al. 1989). All experimental pastures were stocked with yearling cattle from early spring to fall with the goal of $50 \%$ utilization of annual forage production (Stritzke et al. 1991).

\section{Methods}

Deer were captured with a drop net (Ramsey 1968) or Stephenson box trap (Masters 1978); both were baited with whole kernel corn. Deer were ear tagged with numbered cattle tags and fitted with radio transmitters. Whenever possible, each animal was located during 4 activity periods/day (0600-0900, 1200-1500, 1800-2100, and 2200-2400 hours) and 4 days/week during winter (Jan-Feb), spring (Apr-May), summer (Jul-Aug), and fall (Oct-Nov) 1988-89. Three-element Yagi antennae and portable receivers (Wildlife Materials, Inc., Carbondale, IIl.) were used to collect a minimum of 3 compass bearings/location (Heezen and Tester 1967). Compass bearings were taken at 38 treatment intersections throughout the Cross Timbers Experimental Range (CTER) (Soper 1992:78). Locations were plotted in the field on enlarged 1:24,000 U.S.G.S. topographic maps with an overlay of the CTER to insure proper treatment assignment.

Telemetry accuracy was determined with 13 stationary radio transmitters placed at various locations on the CTER that were unknown to observers. Bearing errors ranged from 0 to $17^{\circ}$ and averaged $3^{\circ}$, and average distance from observer to radiocollared deer was $<0.8 \mathrm{~km}$. Given these criteria, our error polygon averaged $1.2 \mathrm{ha}$. Therefore, if an observation was made $>120 \mathrm{~m}$ from a treatment border, observers walked toward the bearing intersection to accurately determine which treatment the animal was in.

Seasonal and annual home ranges were calculated with the $95 \%$ harmonic mean distance method (Dixon and Chapman 1980, Boulanger and White 1990) using McPAAL (M. Stuwe and C. E. Blohowiak, Conserv. Res. Center Natl. Zool. Park, Smithsonian Inst., Front Royal, Va.). A 2-way analysis of variance (SAS Inst. 1985) with sex and season as main effects was used to determine if home range differed in size.

Seasonal habitat use by sex was evaluated with chi-square analyses (Neu et al. 1974, Byers et al. 1984) by comparing the total number of locations observed within a treatment (use) to the total area of each treatment (availability) in composite seasonal home ranges of each sex. Following Gould and Jenkins (1993), we pooled individual deer by sex seasonally for these analyses because we were interested in (1) populational rather than individual responses to treatments and (2) limited sample sizes in some seasons precluded a rigorous evaluation of individual variability in habitat use. Individual deer were not noticeably disparate in their use of the CTER. We analyzed seasonal habitat use by year and also pooled data between years because of small sample sizes in some seasons. When a significant $(P<0.05)$ difference between habitat use and availability occurred, treatment selection or avoidance was inferred by calculating simultaneous 95\% Bonferroni confidence intervals (Neu et al. 1974). Chisquare analyses also were employed for each sex to test specific contrasts that compared deer use of main treatment groups; i.e., fire vs. no fire, triclopyr vs. tebuthiuron, herbicide vs. no herbicide, and treated vs. control.

\section{Results}

Ten female ( $\mathrm{x}$ age $=3$ yrs) and 7 male ( 2 yearlings and $5 \mathrm{ca.} 8$ months old) deer were captured and marked from December 1987 to February 1989. We obtained 3,042 relocations of marked deer with an average of 190 relocations per sex per season (female range $=141-388$; male $=56-305$ ). Annual home range of individual deer averaged 99.9 ha and ranged seasonally from $82.4 \pm$ 8.12 (SE) ha in summer to $122.89 \pm 21.61$ ha in winter. Seasonal home range size did not vary $(P>0.05)$ among seasons or between sexes. 
Considerable variation and differences between sexes existed in use of brush treatments by white-tailed deer (Table 1). For example, both sexes often selected or avoided a particular treatment in a given season in 1 year but not the other. Instances of seasonal selection or avoidance were least common (i.e., an indication of use in proportion to availability) on tebuthiuron and no herbicide + fire treatments. Instances of seasonal avoidance were most prevalent on tebuthiuron + fire and non-treated areas, and instances of seasonal selection were most prevalent on triclopyr + fire treatments. Nevertheless, most treatments $(68 \%)$ were used seasonally in proportion to their availability (Table 1).

To minimize the effect of small sample size in some seasons and maximize our ability to detect significant populational patterns in treatment use by sex, we pooled each season by year. Again, the majority of treatments $(56 \%)$ were neither selected or avoided in most seasons, but avoidance of non-treated areas by both sexes was apparent, particularly in summer and fall (Table 2). Females selected triclopyr treatments in winter and spring, triclopyr + fire treatments in spring, and tebuthiuron + fire treatments in summer and fall. In contrast, males selected triclopyr + fire treatments in summer and fall, non-treated areas in winter, and tebuthiuron treatments in fall. Males were the most particular about treatment use in fall when they selected 2 and avoided 4 treatments (Tablc 2). The seasonal percent similarity of observed use of treatments between sexes decreased linearly from winter through fall (winter $=89.4 \%$, spring $=74.1 \%$, summer $=64.3$, and fall $=54.0 \%$ ); i.e., $54.0 \%$ of the composite home ranges of females and males had the same treatments in common.

Deer use of main treatment groups indicated that females selected or avoided main treatments in 12 of 16 contrasts, but males only selected or avoided treatments in 4 of 16 contrasts (Table 3). Females selected treated areas and avoided non-treated areas in spring, summer, and fall. Females selected tebuthiuron treatments over triclopyr treatments in summer and fall but displayed the opposite in winter. Males did not select or avoid any main treatments in spring but selected fire and triclopyr treatments in fall and treated areas in winter. Both sexes selected fire treatments in summer and were most particular in their choice of main treatments in summer and fall.

\section{Discussion}

Vegetational changes on the Cross Timbers Experimental Range (CTER) have varied with specific brush management treatments and time since application, resulting in widely disparate habitat types (Engle et al. 1991, Stritzke et al. 1991). Wildlife responses to herbicides and prescribed burning on the CTER also have varied among the parasites (Boggs et al. 1990a, 1990b, 1991a, 1991b, Boren et al. 1993a), birds (Boren et al. 1993b, Schulz et al. 1992a, 1992b), and mammals (Lochmiller et al. 1991, 1995, McMurry et al. 1993a, 1993b, 1994, Soper et al. 1993a, 1993b) that we have been able to investigate 3 to 8 years post-treatment. In general, we have documented positive, negative, and neutral effects of the multi-faceted brush management on the CTER to trophic, populational, and nutritional characteristics of individual wildlife species, which have altered parasite burdens, physical condition, and community composition. Because we did not evaluate habitat use by white-tailed deer prior to brush treatment, we cannot conclude that patterns of observed use after treatment represented an overall change in landscape use; however, our observations suggest that some treatments could be of greater benefit to white-tailed deer than others.

Tebuthiuron effectively controlled hardwood species, minimized resprouting, and permitted release of monocot-dominated forage of potentially high seasonal nutritional value (Bogle et al. 1989) to white-tailed deer. However, such areas generally lacked cover preferred by deer (Crawford 1984, Smith 1991). Pooled by year, females selected tebuthiuron + fire treatments in summer and fall, and males selected them without fire only in fall. Forage quality declined markedly in late summer and early fall in untreated cross timbers, but tebuthiuron areas provided an abundant, high quality mix of browse, grasses, and forbs. Relative to pretreatment conditions in 1983 , grass and forb production on tebuthiuron treatments increased $60 \%$ by 1987 compared to tri-

Table 1. Seasonal use, as a percentage of total radio locations, by female and male white-tailed deer of tebuthiuron (Teb) with and without fire, triclopyr (Tric) with and without fire, no herbicides (Herb) with fire, and no brush treatment on the Cross Timbers Experimental Range, Oklahoma.

\begin{tabular}{|c|c|c|c|c|c|c|c|c|c|}
\hline \multirow[b]{2}{*}{ Season } & \multirow[b]{2}{*}{ Sex } & \multirow[b]{2}{*}{$\begin{array}{c}\text { Radiocollared } \\
\text { Deer }\end{array}$} & \multirow[b]{2}{*}{$\begin{array}{l}\text { Radio } \\
\text { Locations }\end{array}$} & \multicolumn{6}{|c|}{ Observed use } \\
\hline & & & & Teb & Teb+Fire & Tric & TrictFire & $\begin{array}{l}\text { No Herbt } \\
\text { Fire }\end{array}$ & $\begin{array}{c}\text { No } \\
\text { Treatment }\end{array}$ \\
\hline & & (No.) & (No.) &.----- & ------- & -----( & 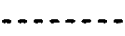 & $---\cdot--$ & ----- \\
\hline \multirow[t]{2}{*}{ Winter 1988} & $\mathbf{F}$ & 8 & 141 & 9.9 & $9.2-^{1}$ & 38.3 & $25.5+$ & 2.2 & 14.9 \\
\hline & $\mathbf{M}$ & 3 & 107 & 12.1 & 11.2 & 38.3 & 20.6 & $4.7-$ & 13.1- \\
\hline \multirow[t]{2}{*}{ Spring 1988} & $\mathbf{F}$ & 6 & 174 & 9.8 & $11.5-$ & 24.7 & $14.4+$ & 23.5 & 16.1 \\
\hline & $\mathbf{M}$ & 3 & 67 & 14.9 & 9.0 & 31.3 & 34.3 & $1.5-$ & 9.0 \\
\hline \multirow[t]{2}{*}{ Summer 1988} & $\mathbf{F}$ & 4 & 203 & 9.4 & 20.2 & 23.6 & 15.3 & 17.7 & 13.8 \\
\hline & $\mathbf{M}$ & 2 & 85 & 14.1 & 15.3 & 9.4 & 40.0 & 0 & 21.2 \\
\hline \multirow[t]{2}{*}{ Fall 1988} & $\mathbf{F}$ & 6 & 211 & 6.2 & 20.4 & 21.3 & $2.8-$ & 13.8 & 35.5 \\
\hline & $\mathbf{M}$ & 2 & 56 & 46.4 & 5.4 & $1.8-$ & $42.9+$ & 0 & 3.5 \\
\hline \multirow[t]{2}{*}{ Winter 1989} & $\mathbf{F}$ & 5 & 168 & $29.8+$ & 16.7 & $19.0+$ & 5.9 & 3.0 & 25.6 \\
\hline & $M$ & 5 & 204 & 29.9 & 5.9 & 15.7- & 14.2 & 0.5 & $18.4+$ \\
\hline \multirow[t]{2}{*}{ Spring 1989} & $\mathbf{F}$ & 5 & 209 & 15.7 & 20.6 & $35.9+$ & 4.3 & 4.8 & 18.7- \\
\hline & $\mathbf{M}$ & 5 & 170 & 16.5 & 9.4 & 21.8 & 25.3 & 0.6 & 26.4 \\
\hline \multirow[t]{2}{*}{ Summer 1989} & $\mathbf{F}$ & 5 & 388 & 19.6 & $29.4+$ & $21.1+$ & 4.1 & 3.1 & $22.7-$ \\
\hline & $\mathbf{M}$ & 4 & 305 & 15.4 & 8.0 & 12.5 & $22.2+$ & 0.3 & $41.6-$ \\
\hline \multirow[t]{2}{*}{ Fall 1989} & $\mathbf{F}$ & 5 & 342 & 26.3 & $31.3+$ & 15.2 & 7.6 & 2.6 & 17.0 \\
\hline & $\mathbf{M}$ & 3 & 212 & $11.4 t$ & 3.3 & $0.9-$ & $28.3+$ & 0.9 & $55.2-$ \\
\hline
\end{tabular}

${ }^{1}$ Significant selection ( + ) or avoidance $(-)$ of treatments relative to availability from simultaneous $95 \%$ Bonferroni confidence intervals (Nue et al. 1974). 
Table 2. Seasonal use (1988 and 1989 pooled), as a percentage of total radio locations, by female and male white-tailed deer of tebuthiuron (Teb) with and without fire, triclopyr (Tric) with and without fire, no herbicides (Herb) with fire, and no brush treatment on the Cross Timbers Experimental Range, Oklahoma.

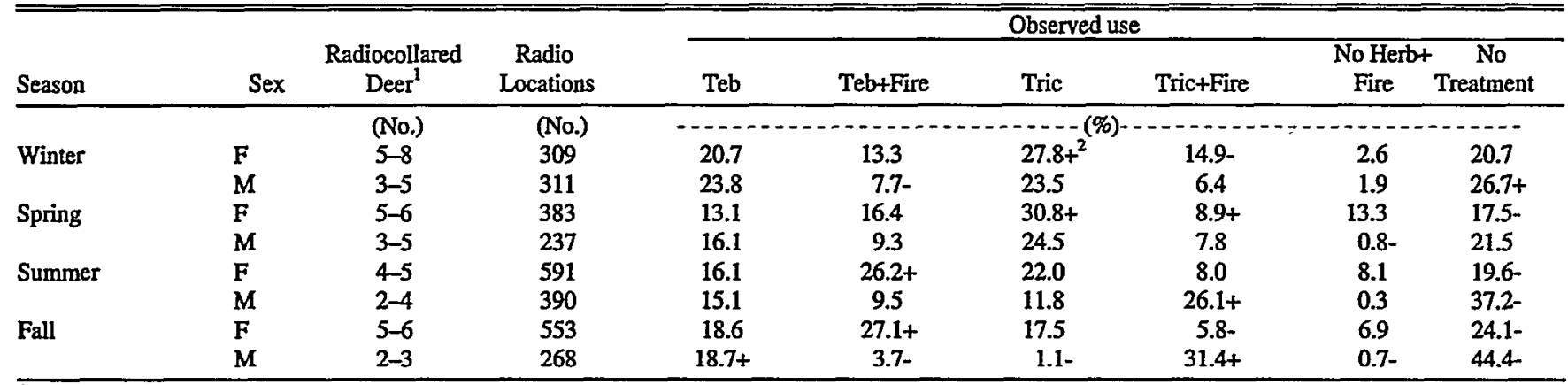

Range of radiocollared deer in combined seasons.

${ }^{2}$ Significant selection $(+)$ or avoidance $(-)$ of treatments relative to availability from simultaneous $95 \%$ Bonferroni confidence intervals (Neu et al. 1974).

clopyr treatments and 7,000\% compared to control areas (Engle et al. 1991, Stritzke et al. 1991), which coupled with low forage quality on other parts of the CTER likely attracted deer to them.

Triclopyr was less effective at removing woody overstory species than tebuthiuron and was ineffective at controlling resprouting, which resulted in abundant browse production with concomitant suppression of herbaceous forage production (Engle et al. 1991). We speculated that triclopyr-treated areas would be particularly attractive to deer because of the increased midstory vegetation, which would provide abundant (Stritzke et al. 1991) and nutritious (Soper et al. 1993a) browse and dense horizontal cover (Schulz et al. 1992a). Pooled by year, female deer selected triclopyr treatments, sometimes in combination with prescribed burning, in winter and spring, and males selected them in summer and fall. Selection of triclopyr treatments by females coincided with gestation when nutrition and protective and thermal cover are important (Dusek et al. 1989, Smith 1991). In contrast, males selected triclopyr treatments during antler growth in summer when nutrition was critical (Hesselton and Hesselton 1982).

Prescribed burning, with or without herbicides, did not completely control regrowth of woody overstory species because of insufficient fuel loads, but it did increase seasonal gains in body mass of cattle by $24 \%$ compared to $8 \%$ improvement in gains on unburned herbicide-treatments (McCollum et al. 1987). Because of (1) that positive nutritional influence to cattle, (2) prolonged forb production when burning and herbicides were used together (Engle et al. 1991), and (3) positive effects of brush treatment on weights of deer (Soper et al. 1993b), we speculated that deer would select burned areas, at least seasonally. Pooled by year, female deer selected burned treatments, sometimes in combination with herbicides, in spring, summer, and fall, but males selected them only in summer. Any nutritional gain obtained by females during late gestation (spring), lactation (summer), and prior to breeding (fall) from burned treatments would be advantageous. Similarly, male deer could have derived benefit during antler growth in summer and prior to rut on burned treatments.

Our analyses of main treatment groups supported our hypothesis that deer would select treated areas over untreated areas; however, females were considerably more selective of human-altered habitats than males. Females selected fire treatments in 2 of 4 seasons and herbicide treatments in 3 of 4 seasons, and they avoided control areas in 3 of 4 seasons. In contrast, males only selected fire treatments in 2 of 4 seasons and avoided control areas in 1 of 4 seasons. No clear pattern of selection or avoidance of triclopyr and tebuthiuron treatments was apparent for either sex. The disparities in selection and avoidance of main treatment groups by male and female deer supported our hypothesis of differential habitat use between sexes. The greatest percent similarity in composite home ranges occurred in winter (89.4\%), and the least occurred in fall when $54 \%$ of habitats in respective ranges were disparate. McCullough et al. (1989) also observed the highest overlap between female and male white-tailed deer in Michigan in January (ca. 65\%), but it was lowest (40.8\%) during fawning in May. The considerably higher peak overlap in winter in our study compared to McCullough et al. (1989) probably was due to our radiocollared sample of males that was dominated by

Table 3. Seasonal contrasts of main treatment groups, as a percentage of total radio locations, by female and male white-tailed deer on the Cross

Timbers Experimental Range, Oklahoma, 1988-1989.

\begin{tabular}{|c|c|c|c|c|c|}
\hline \multirow[b]{2}{*}{ Season } & \multirow[b]{2}{*}{ Sex } & \multicolumn{4}{|c|}{ Contrasts of observed use } \\
\hline & & Fire vs. No Fire & Herbicide vs. No Herbicide & Tric vs. Teb & Treated vs. Control \\
\hline & & $-n$ & $(\%)$ & - & - \\
\hline \multirow[t]{2}{*}{ Winter } & $F$ & $30.7-/ 69.3++^{1}$ & $76.7 / 23.3$ & $55.7+144.3-$ & $79.3 / 20.7$ \\
\hline & $\mathbf{M}$ & $26.0 / 74.0$ & $71.4 / 28.6$ & $55.8 / 44.2$ & $73.3+/ 26.7-$ \\
\hline \multirow[t]{2}{*}{ Spring } & $\mathbf{F}$ & $43.9+/ 56.1-$ & $69.2+/ 30.8-$ & $57.4 / 42.6$ & $82.5+/ 17.5-$ \\
\hline & $M$ & $38.0 / 62.0$ & $77.6 / 22.4$ & $67.4 / 32.6$ & $78.5 / 21.5$ \\
\hline \multirow[t]{2}{*}{ Summer } & F & $42.3+157.7$ & $72.2+/ 27.8$ & $41.4-158.6+$ & $80.4+/ 19.6$ \\
\hline & M & $35.9+/ 64.1-$ & $62.6 / 37.4$ & $60.6 / 39.4$ & $62.8 / 37.2$ \\
\hline \multirow[t]{2}{*}{ Fall } & $\mathbf{F}$ & $39.8 / 60.2$ & $69.1+/ 30.9$ & $33.8-/ 66.2+$ & $75.9+/ 24.1-$ \\
\hline & $\mathbf{M}$ & $36.5+/ 63.5-$ & $54.8 / 45.2$ & $59.2+/ 40.8$ & $55.6 / 44.4$ \\
\hline
\end{tabular}

${ }^{1}$ Significant selection ( + ) or avoidance $(-)$ of treatment contrasts relative to availability from simultaneous $95 \%$ Bonferoni confidence intervals (Neu et al. 1974). 
individuals $<2$ years old; yearling males probably were still using areas of, or associating with, their natal family groups (Hirth 1977, Dusek et al. 1989). Nevertheless, sexual segregation in white-tailed deer occurs seasonally and theoretically minimizes intersexual competition (McCullough et al. 1989).

Females selectively used the mosaic of herbicide and burned treatments on the Cross Timber Experimental Range (CTER) to a considerably greater extent than males and demonstrated some degree of selection in all seasons, coincident with major periods of reproduction. Although we did not observe increased production of fawns on the CTER compared to a nearby non-treated area (Soper et al. 1993a), it is possible that survival of offspring was enhanced due to human-altered habitats on the CTER. Males may benefit nutritionally on the CTER as they grow antlers and ready themselves for rut, but they were not particularly selective of specific treatments. Because our sample of males was small and 5 of 7 radiocollared males were $<2$ years old, we view these conclusions as tentative. We concur with Soper et al. (1993b) who concluded that the mosaic of habitat types resulting from a variable herbicide and burn application pattern enhances cross timbers rangeland for both white-tailed deer and livestock and thereby, has the potential to increase economic returns to landowners (Bernardo and Engle 1990, Bernardo et al. 1992).

\section{Literature Cited}

Beasom, S. L. and C. J. Scifres. 1977. Population reactions of selected game species to aerial herbicide applications in south Texas. J. Range Manage. 30:138-142.

Beasom, S. L., J. M. Inglis, and C. J. Scifres. 1982. Vegetation and white-tailed deer responses to herbicide treatments of a mesquite drainage habitat type. J. Range Manage. 35:790-794.

Bernardo, D. J. and D. M. Engle. 1990. The effect of manager risk attitudes on range improvement decisions. J. Range Manage. 42:242-249.

Bernardo, D. J., D. M. Engle, R. L. Lochmiller, and F. T. McCollum. 1992. Optimum vegetation management under multiple use objectives in the Cross Timbers. J. Range Manage. 45:462-467.

Bogle, L. A., D. M. Engle, and F. T. McCollum. 1989. Nutritive value of range plants in the cross timbers. Okla. Agr. Exp. Sta. Res. Rep. P908.

Boggs, J. F., R. L. Lochmiller, S. T. McMurry, D. M. Leslie, Jr., and D. M. Engle. 1991a. Cuterebra infections in small-mammal communities as influenced by herbicide and fire. J. Mammal. 71:322-327.

Boggs, J. F., S. T. McMurry, D. M. Leslie, Jr., D. M. Engle, and R. L. Lochmiller. 1990a. Influence of habitat modification on the intestinal helminth community ecology of cottontail rabbit populations. J. Wildl. Dis. 26:157-169.

Boggs, J. F., S. T. McMurry, D. M. Leslie, Jr., D. M. Engle, and R. L. Lochmiller. 1990b. Parasitism of cottontail rabbits (Sylvilagus floridanus) by Obeliscoides cuniculi in response to habitat modification in the Cross Timbers of Oklahoma. J. Helminth. Soc. Wash. 57:146-152.

Boggs, J. F., S. T. McMurry, D. M. Leslie, Jr., D. M. Engle, and R. L. Lochmiller. 1991a. Influence of habitat modification on the community of gastrointestinal helminths of cotton rats. J. Wildl. Dis. 27:584-593.

Boren, J. C., R. L. Lochmiller, J. F. Boggs, D. M. Leslie, Jr., D. M. Engle, and H. E. Jordan. 1993a. Responses of intestinal nematodes in white-footed mouse (Peromyscus leucopus) popluations to rangeland modification. Proc. Okla. Acad. Sci. 73:39-44.

Boren, J. C., R. L. Lochmiller, D. M. Leslie, Jr., and D. M. Engle. 1993b. Long-term effects of woody vegetation management on seasonal body condition of northern bobwhites. J. Range Manage. 46:520-523.

Boulanger, J. G. and G. C. White. 1990. A comparison of home-range estimators using Monte Carlo simulation. J. Wildl. Manage. $54: 310-315$.
Byers, C. R., R. K. Steinhorst, and P. R. Krausman. 1984. Clarification of a technique for analysis of utilization-availability data. J. Wildl. Manage. 48:1050-1053.

Crawford, H. S. 1984. Habitat management, p. 629-649. In: L. K. Halls (ed). White-tailed deer: ecology and management. Stackpole Books, Harrisburg, Penn.

Darr, G. W. and D. A. Klebenow. 1975. Deer brush control and livestock on the Texas rolling plains. J. Range Manage. 28:115-119.

Davis, R. B. and C. K. Winkler. 1968. Brush vs. cleared range as deer habitat in southem Texas. J. Wildl. Manage. 32:321-329.

Dixon, K. R. and J. A. Chapman. 1980. Harmonic mean measure of animal activity areas. Ecol. 61:1040-1044.

Dusek, G. L., R. J. Mackie, J. D. Herriges, Jr., and B. B. Compton. 1989. Population ecology of white-tailed deer along the lower Yellowstone River. Wildl. Monogr. 104:1-68.

Engle, D. M., J. F. Stritzke, and F. T. McCollum. 1991. Vegetation management in the cross timbers: response of understory vegetation to herbicides and burning. Weed Tech. 5:406-410.

Ewing, A. L., J. F. Stritzke, and J. D. Kulbeth. 1984. Vegetation of the Cross Timbes Experimental Range, Payne County, Oklahoma. Okla. Agr. Exp. Sta. Res. Rep. P-856.

Fulbright, T. E. and A. Garza, Jr. 1991. Forage yield and white-tailed deer diets following live oak control. J. Range Manage. 44:451-455.

Garrison, G. A., A. J. Bjugstad, D. A. Duncan, M. E. Lewis, and D. R. Smith. 1977. Vegetation and environment features of forest and range ecosystems. U.S. For. Serv. Agr. Hanb. No. 475.

Gould, J. H. and K. J. Jenkins. 1993. Seasonal use of Conservation Reserve Program lands by white-tailed deer in east-central South Dakota. WildI. Soc. Bull. 21:250-255.

Gray, F. and C. Stanke. 1970. Classification of soils in the savannahforest transition in eastern Oklahoma. Okla. Agri. Exp. Sta. Bull. B$672.51 \mathrm{p}$.

Heezen, L. K. and J. R. Tester. 1967. Evaluation of radio-tracking by triangulation with special reference to deer movements. J. Wildl. Manage. 31:124-141.

Hesselton, W. T. and R. M. Hesselton. 1982. White-tailed deer, p. 878-901. In: J. A. Chapman and G. A. Feldhamer (eds). Wild mammals of North America: biology, management, and economics. Johns Hopkins Univ. Press, Baltimore, Md.

Hirth, D. H. 1977. Social behavior of white-tailed deer in relation to habitat. Wildl. Monogr. 53:1-55.

Inglis, J. M. 1983. Brush control and wildlife management in south Texas, p. 69-71. In: K. C. McDaniel (ed). Proceedings of the Brush Management Symposium. Soc. Range Management, Denver, Colo. $105 \mathrm{p}$.

Jenks, J. A., D. M. Leslie, Jr., R. L. Lochmiller, and M. A. Melchiors. 1994. Variation in gastrointestinal characteristics of male and female white-tailed deer: implications for resource partitioning. J. Mammal. 75:1045-1053.

Lochmiller, R. L., F. F. Boggs, S. T. McMurry, D. M. Leslie, Jr., and D. M. Engle. 1991. Response of cottontail rabbit populations to herbicide and fire applications on cross timbers rangeland. J. Range Manage. 44:150-155.

Lochmiller, R. L., D. G. Peitz, S. T. McMurry, D. M. Leslie, Jr., and D. M. Engle. 1995. Alterations in condition of cottontail rabbits (Sylvilagus floridanus) on rangelands following brush management. J. Range Manage. 48:232-239.

Masters, R. 1978. Deer trapping, marking and telemetry techniques. The Archer and Anna Huntington Wildl. For. Sta., Newcomb, N.Y. 72 p.

McCollum, F. T., D. M. Engle, and J. F. Stritzke. 1987. Brush management on the cross timbers experimental range: III. Carrying capacity and steer performance. Okla. Agr. Exp. Sta. Res. Rep. 110-113.

McCullough, D. R., D. H. Hirth, and S. J. Newhouse. 1989. Resource partitioning between sexes in white-tailed deer. J. Wildl. Manage. 53:277-283.

McMurry, S. T., R. L. Lochmiller, J. F. Boggs, D. M. Leslie, Jr., and D. M. Engle. 1993a. Woodrat population dynamics following modification of resource availability. Amer. Midl. Nat. 129:248-256. 
McMurry, S. T., R. L. Lochmiller, J. F. Boggs, D. M. Leslie, Jr., and D. M. Engle. 1993b. Opportunistic foraging of eastern woodrats (Neotoma floridana) in manipulated habitats. Amer. Midl. Nat. 130:325-337.

McMurry, S. T., R. L. Lochmiller, J. F. Boggs, D. M. Leslie, Jr., and D. M. Engle. 1994. Demographic profiles of cotton rat populations in a continuum of habitat types. J. Mammal. 75:50-59.

Neu, C. W., C. R. Byers, and J. M. Peek. 1974. A technique for analysis of utilization-availability data. J. Wildl. Manage. 38:541-545.

Quinton, D. A., R. G. Horejsi, and J. T. Flinders. 1979. Influence of brush-control on white-tailed deer diets in north-central Texas. J. Range Manage. 32:93-97.

Ramsey, C. W. 1968. A drop-net deer trap. J. Wildl. Manage. 32:187-190.

Rollins, D. 1987. Brush management and wildlife, p. 42-50. In: D. Rollins (ed). Proceedings of Brush Management in the Cross Timbers. Okla. coop. Ext. Serv. Circ. E-862. 56 p.

Rollins, D., F. C. Bryant, D. D. Waid, and L. C. Bradley. 1988. Deer response to brush management in central Texas. Wildl. Soc. Bull. 16:277-284.

SAS Institute. 1985. Procedures guide. Statistical Analysis System, Inc., Cary, N.C.

Schulz, C. A, D. M. Leslie, Jr., R. L. Lochmiller, and D. M. Engle. 1992a. Herbicide effects on cross timbers breeding birds. J. Range Manage. 45:407-411.

Schulz, C. A. D. M. Leslie, Jr., R. L. Lochmiller, and D. M. Engle. 1992b. Autumn and winter bird communities on herbicide-treated cross timbers in Oklahoma. Amer. Midl. Nat. 127:215-223.
Scifres, C. J. 1980. Brush management: principles and practices for Texas and the southwest. Texas A\&M Press, College Station, Tex. $360 \mathrm{p}$.

Scifres, C. J. and J. L. Mutz. 1978. Herbaceous vegetation changes following applications of tebuthiuron for brush control. J. Range Manage. 31:375-378.

Smith, W. P. 1991. Odocoileus virginianus. Mammal. Species 388:1-13.

Soil Conservation Service. 1981. Land resource regions and major land resource areas of the United States. USDA Handb. No. 296.

Soper, R. B. 1992. Effects of brush management on white-tailed deer (Odocoileus virginianus) in the cross timbers region of Oklahoma. M.S. Thesis, Okla. State Univ., Stillwater, Okla. 85 p.

Soper, R. B., R. L. Lochmiller, D. M. Leslie, Jr., and D. M. Engle. 1993a. Nutritional quality of browse after brush management on cross timbers rangeland. J. Range Manage. 46:399-410.

Soper, R. B., R. L. Lochmiller, D. M. Leslie, Jr., and D. M. Engle. 1993b. Condition and diet quality of white-tailed deer in response to vegetation management in central Oklahoma. Proc. Okla. Acad. Sci. 73:53-61.

Stritzke, J. F., D. M. Engle, and F. T. McCollum. 1987. Brush management on the cross timbers experimental range: 1 . Brush problems and responses to herbicides. Okla. Agric. Exp. Stn. Res. Rep. MP119:99-102.

Stritzke, J. F., D. M. Engle, and F. T. McCollum. 1991. Vegetation management in the cross timbers: response of woody species to herbicides and burning. Weed Tech. 5:400-405.

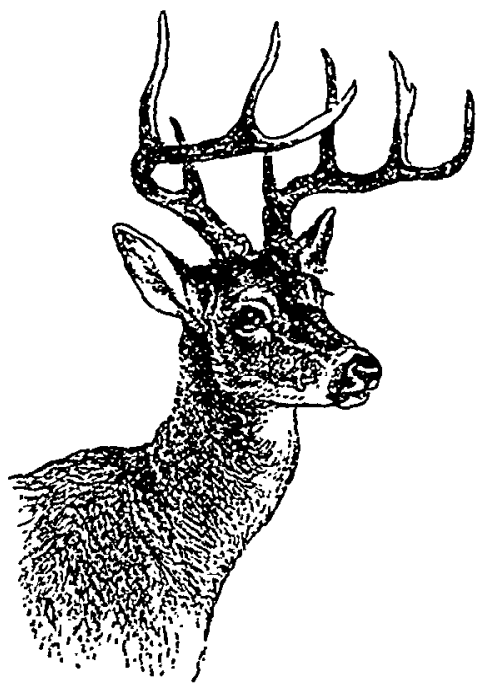

